\title{
ARTICLES
}

\section{LOVE AND FORGIVENESS IN GOVERNANCE ${ }^{1}$}

\author{
Syed Hamid Albar ${ }^{*}$
}

What is lacking in our world today? Why are so many parts of the globe experiencing conflict? In my view, there is an absence of love and forgiveness which brings us to our current state. We see it in Europe, the Middle East, and even in Asia. The current conflicts within or amongst nations and people are mostly due to the detachment of our outer self from our inner self. Remember that human beings are all children of Adam, and God in His wisdom created us all differently so that we may learn to harness our sense of love and forgiveness towards each other. The word "love" here refers to a desire for good and for the benefit to come to others (Hamza Yusuf, 2012:19). Admittedly, there exists good and evil in all of us, and when we react to situations using our base instincts (our outer self so to speak), there is always the possibility of evil coming to the fore.

For example, when someone harms us on a thoughtless impulse, we may seek to react in a similar manner by inflicting equivalent harm or worse with more punitive outcome upon the perpetrator. This could result in our achieving physical satisfaction. However doing this will only perpetuate hatred, revenge and conflict, and thereby we are no better than the perpetrator of the harm.

Hate is the absence of love, and only through love can hatred be removed from the heart. Arguably, the disease of hatred is one of the most devastating forces in the world. But the force that is infinitely more powerful is love. Love is an attribute of God, hate is not. A name of God mentioned in the Quran is Al-Wadud, the loving one. Hate is absence of love and only through love can hatred be removed from the heart. In a beautiful hadith, the prophet said, "none of you has achieved faith until he loves for his brother what he loves for himself". According to Imam al-Nawawi, when the Prophet (s.a.w) says "brother" we should interpret this as universal brotherhood, which includes Muslims and non-Muslims (Hamza Yusuf, 2012:19).

Therefore, we must never allow our emotions to get the better of our inner self. Instead we should search within ourselves for the desire for 'forgiveness', which would in turn perpetuate understanding and respect for one another and begin a 
journey toward a more peaceful world, where everyone may share happiness and prosperity. This requires self-awareness and inner strength to tamp down the evil impulses and allow the good to come to the surface.

When I say there is an absence of love and forgiveness, I don't mean that we do not love our families or forgive our friends. This certainly is there. What is lacking is the capacity to approach the "stranger" or the "other" with love and forgiveness. This can only be manifested when we consciously decide to approach issues in a sincere spirit of love and forgiveness, in other words to internalise reliance on love and forgiveness as guiding principles when dealing not just with family and friends but everyone. This implies making love and forgiveness key aspects of our mechanism for governance. According to Desmond Tutu in his book of Forgiving: The Fourfold path for Healing Ourselves and our World, forgiveness is truly the grace by which we enable another person to get up, and get up with dignity, to begin anew. To not forgive leads to bitterness and hatred. Like selfhatred and self-contempt, hatred of others gnaws away at our vitals. Whether hatred is projected out or stuffed in, it is always corrosive to the human spirit.

Therefore there is a need to search our innerself through muhāsabah ('selfoversight'). Without this we would not be able to understand and/or inculcate the feelings of love, compassion and forgiveness amongst beings created by God. God made the human to be vicegerent on earth - we were not created for conflict, rather to love and learn from each other. In this way we may create a community of people, a community of nations, and a community of states that could interact with each other to benefit from the universe created by God for us. Love and forgiveness are the prerequisites to turn these objectives into realities.

Love and forgiveness may be idealistic principles but they are not passive principles. They are very active principles requiring us to actively manage the two most significant human qualities: namely our minds and emotions. Love and forgiveness must have a connection with the temporal world. Granted: they cannot be the only principles that we use for governance. We may be idealistic but we are not blind. Undoubtedly evil exists in our world and must be confronted forcefully. But even when we are forced to confront evil, we have a choice of how to confront it, using a spirit of love and forgiveness or using a spirit of hatred and vengeance. History has given countless examples of which is the better approach.

This year 2014 is the centenary of the First World War; let us therefore examine how this war was prosecuted-ruthlessly and with vengeance. The spirit of vengeance was best reflected in the victor's peace imposed on a defeated Germany with punitive reparations and the like. The result was truly tragic in its predictability. Another World War broke out 30 years after that. By contrast, the end of the Second World War was a different story altogether when Western powers eschewed punitive reparations and treated West Germany as an ally. De 
Gaulle and Adenauer rose above their nations' historical enmity and in the spirit of love and partnership formed an enduring partnership for over seventy years, a partnership that has banished the spectre of war between France and Germany.

\section{Sourced in Divine Attributes}

The feelings of love and forgiveness are timeless qualities of God which are sourced in the divine Attributes of Mercy and Compassion (al-Rahmān al-Rahīm). These two qualities seem to be lacking in our world today. When confronted by conflict or disagreement between peoples or nations, there is a strong tendency to pursue it to the death. Such a tendency assumes we should solve problems premised on anger and revenge. In these circumstances we fail to base our intent for resolving conflicts upon considerations of love and forgiveness. Our emotions will usually drive us in one direction, whilst our mind may direct us to think deeper in order to prevent us from acting irrationally. This is why I say that love and forgiveness are active principles requiring us to think deeper and to act differently.

The conflicts around the globe that confront us today arise because we are really not looking for solutions to achieve reconciliation and peace, but rather seeking revenge on the principle of 'an eye for an eye'. We forget what Mahatma Gandhi once said-'An eye for an eye leaves the whole world blind!' The cardinal principle of conflict resolution is the willingness to reach a new frontier of forgiveness - the understanding of forgiveness demonstrated by the likes of Nelson Mandela and Mahatma Gandhi. The Prophet of Islam, Muhammad (peace be upon him), and the prophets before him did not have in them even a tinge of hate and anger. The Prophet Muhammad (pbuh) possessed tremendous qualities of humility, love, patience, perseverance and forgiveness. It was this spirit of love and forgiveness which enabled the Prophet to be so "supremely successful" in both the temporal and secular realms. These are not my own words, but are the conclusion drawn by Michael Hart in his 1978 book 100 Most Influential Persons in History - where Hart ranked Prophet Mohammad no. 1. If love and forgiveness were good enough for the most influential person in history, it is my humble submission that it should be good enough for the rest of us.

Indeed every human being may possess love and forgiveness, which is sourced in Compassion as a divine quality. In the present day this quality appears to be lacking especially in the Arab world. Failure in the Arab world to find reconciliation and resolution is due to the absence of love and forgiveness. They debate and confront each another without any desire to compromise and accommodate; each claims to be in the right on the basis of anger, or in retribution for what the other had done. Anger and violence then become the order of the day, although God had endowed them and their countries with enough material wealth. However, material wealth without love and forgiveness comes to nought. 


\section{Idealism over Realism}

In my experience, in politics people tend to be Machiavellian though they may deny it; that is a major problem confronting humans (Machiavelli: 1532). I do not accept Hobbes's conception of "state of nature" when he asserted that human beings are by nature bad, solitary, nasty and brutish (Giampietri C: 2008) or the belief that "every human being is born a sinner and salvation would only be possible after that" (Matt P: 2006). For Muslims, our belief is that every human being is born like a clean sheet of paper. In this respect, the Muslim conviction concerning the original nature of Man in his primordial state is similar to the Rawlsian philosophy of justice which assumes that Man in his original state is neutral and predisposed towards justice (Richardson HS). It is our environment and upbringing that makes us what we are. There is much disagreement over the understanding of these principles; while the way dogmas are being practised or interpreted is itself a problem. Islam instructs us to rely upon "Hablu min Allah" and "Hablu min al-nās" (a rope from God, and a rope from people; see Q 3:112) - to forge strong ties with God and with our fellow humans. A meaningful relationship can only exist when there is love. Thus, in order to be complete our love of God should not be limited to God alone, but must also extend to love between fellow human beings.

When these principles are extended to the governance of the State or even of corporate entities, then we require leaders at the national, regional and international levels who both possess and practice love and forgiveness. Admittedly this is easier said than done, since those who are sincere and honest are found to be few, and for that matter they rarely survive in the harsh political environment. Machiavelli advocated politics and governance whereby the end justifies the means - in other words, we don't require ethics and moral values for means of governance. Yet without clean, honest and sincere leaders we would be governed by the law of the jungle led by leaders who are unscrupulous and corrupt. Neither is this sustainable, since those who are wronged will only be waiting for an opportunity to strike back thereby unleashing another cycle of strife and conflict.

For a lasting peace, for a sustainable peace, it is critical that ethics and principles be at the forefront of all that our leaders do. It is thus critical that sincere and honest leaders not simply withdraw from the political scene. If states are led only by corrupt and materially greedy leaders then we would inhabit a cruel unforgiving world. Unfortunately, the political realities appear to make it expedient to be amoral. Often it is said: "either you kill your competitor, or be killed by your opponent or rival". This implies that being compromising, accommodative, loving or forgiving is not the norm and is too idealistic to follow. 
Thus, the definitions of love and forgiveness become more complex. Frequently love and forgiveness are used not merely for reconciliation and conflict resolution, but are also now being employed as a tool to gain political mileage. So it is not at all surprising that conflicts are brewing everywhere in the world today!

Without being parochial, I would say that Malaysia's founding fathers exemplified this ideal in practice. They exhibited love not just for their own respective communities, but also the other communities in their country. Considering that the different communities lived in totally compartmentalised and self-contained worlds, this was indeed far-reaching and laid the foundations for nation-building so that Malaysia is one of the most successful countries in Asia by any objective measure.

Governance comes with responsibility. Hate and anger do not recognise responsibility but are fed by lust, greed and selfish emotions. What would responsible governance mean to them? For people possessing love and forgiveness within themselves, when governing they would include the elements of righteousness, virtue, goodwill, trust and sincerity. But those who are driven by hate, vengeance, anger and greed, once given power would exercise that power irresponsibly. For example, Adolf Hitler was a charismatic nationalistic leader who lacked ethical moral values, and therefore caused much suffering and destruction because of his ambition and greed.

What we are today can be attributed to the environment we live in and the education system that we went through. The education system worldwide must therefore include in their syllabi teachings on love and forgiveness between human beings, human beliefs, and the environment. We should not focus our education solely on material pursuits. Education cannot be done in a vacuum, but must be delivered in an ethical context and its outcomes measured not just by how many students pass, but also what values they imbibe and practice.

I strongly believe our lives should be driven by the sense of justice, fairness and moderation, and that it has to be founded on the rule of law. These concepts are all interrelated. I am reminded of the statement by the Nobel Peace Prize winner Aung San Su Kyi- "Law and Order without being infused by justice is just tyranny". The pursuit of international justice and rule of law are lauded everywhere and considered to be worthy virtues, but this is evident in their application. Generally the rule of law and justice have become selective in practice and application. Often they are practised based on affiliations and profiling, rather than objective merit. Even an icon like Aung San Su Kyi did not practice what she preached when confronted by the difficulty of applying these worthy principles. Despite the persecutions suffered by the Rohingya at the hands of the majority Burmese community, she has not uttered a word of support for the Rohingya community or a word of condemnation against those persecuting them. 
In international relations we have the paradoxical situation where countries whose internal political arrangements are admirably democratic and infused with principles of justice, love and forgiveness, do not appear to practice them when it comes to relations toward other countries. The bottom line for the major global powers seems to be how to dominate or impose standards and exercise hegemony on smaller and weaker countries. It is as if for them love and forgiveness stops at the water's edge. That is why in the beginning of my essay I stressed that we have to extend these same principles to the "stranger" and to the "other" in addition to our family and friends. For this reason we need more people who are idealists and constructivists, who believe in human ideals based on ethical values, so as to create an international system that is more balanced and just. Regrettably such qualities are mostly found amongst the academics and not in the real world of international politics.

\section{Lessons from the Past for Good Governance}

Based on the revealed Qur'an and Prophetic Hadiths, Islamic teachings state that history is a good teacher to learn lessons from the past, to have role models as worthy examples of iconic leaders or those we may emulate and learn from. This would prevent us from repeating the same mistakes of the past. In so far as love and forgiveness are concerned we could do no better than to follow our beloved seal of all prophets, Saiyidina Muhammad (pbuh), as his approach were always tempered with love and forgiveness even towards those who humiliated, harmed or hated him.

Love and forgiveness definitely have an important role for good governance. Governance describes the way we should manage the affairs of states and governments to achieve the desired objectives of nation states-namely, maintaining positive and constructive international relations at the bilateral and multilateral levels in order to enable peoples and nations to mutually benefit and live in peace, harmony and security. We have tried to realise this in the umbrella organisation ASEAN.

A country's leader must focus on what the government should do to benefit the nation and its citizens. Good governance means whatever we do must not be for personal benefit or for the benefits of our family members. This can only be achieved when love and forgiveness are made central to governance. Given this responsibility, a true leader must never betray the responsibility entrusted with him. Today we have become a very materialistic society and many of us have forgotten the very essence of good governance. Islamic teachings convey that responsibility must be performed and guided by four core values:

- Șidq (upholding truth)

- Amānah (being trustworthy) 
- Tabligh (being able to communicate effectively)

- Fațannah (to have wisdom)

Only by truly practising these core values can one avoid corruption. A leader must be able to look straight in the eyes of citizens and state the government is doing the right thing. Further, a leader who practices love and forgiveness in governance and in the decision making process can certainly contribute to ending conflicts amicably or at the very least mitigating the effects of conflicts from spilling out uncontrollably within the society. A good judge has to dispense justice based on law, facts and evidence. A good conscientious judge is one who not only weighs the law and evidence before him, but will also consider the full circumstances of the case before meting out any sentence or pronouncing judgment. For example, a thief who steals bread for his children out of desperation should not be treated in the way as a common thief who steals as part of his way of life, although the law may allow the judge to impose such punishment. In my view, a conscientious judge is a judge filled with compassion, love and forgiveness.

In discharging administrative functions as well love and forgiveness play an important role, otherwise officials will be reduced to mere machines with no feelings and compassion. While due process of law must be upheld without any interference or prejudices, the detachment of love and forgiveness in exercising these functions and duties will not bring justice and fairness. Love and forgiveness in governance do not mean that the law must take a back seat-rather they are factors which keep one in authority in check for those with power to discharge his or her duty conscientiously, and be just and fair and without fear or favour. Here the question of legitimacy arises. Where do we draw the line and who gets to draw the line? What is the basis for our decisions? Ultimately for democrats, the sovereign will of the people is paramount, and so for our actions to be considered legitimate, the majority of the people have to see them as just and necessary. The powers of discretion given to those with administrative responsibilities must have clear guidelines to ensure that discretion does not degenerate into capriciousness.

When I was on the bench as a judicial officer, I often pondered upon these questions before meting out any sentence on the accused person:

- whether the evidence has been weighed properly and correctly;

- whether there exists any prejudices arising from the Prosecution's submission and presentation;

- whether there is any emotion which might have influenced the judgment;

- whether there exists any discretion in the law to consider the mitigating circumstances which would allow a lesser sentence to be passed.

Similar considerations were also experienced when I served as a Home Minister and had to discharge my duties under the now repealed Internal Security Act. 
Many criticised the application of this particular law, but at the same time they did not care to admit that this law was duly passed in Parliament by the majority and therefore, by extension, it was the wish of the majority of the population to live in peace and security. The idea of a Preventive Law is to prevent certain situations from happening or acts committed to the detriment of the society. This would threaten both security and law and order. The Preventive Law is intended to deal with matters that allow for the maintenance of peace, security and stability. It should be realised that the application of the ISA was not totally without due process - the detainee could apply for "habeas corpus" to order the Minister or officials to release the detained person. Within six months of his detention the detainee could apply to a Tribunal to review his detention and determine whether the Minister had rightly exercised his power. Otherwise the Court or the Tribunal would order the release of the detainee.

In comparison to laws in other countries, the Malaysian ISA may be said to have had more built-in safeguards than e.g. the Patriot Act or the Guantanamo Bay detention process. The decision of the Home Minister to sign a detention order under the ISA was not done at the Minister's own whims and fancy, but after taking into considerations all issues as advised by the intelligence agencies that the interest of the nation and society has to be protected from potential threats to security of the Federation. Naturally, this issue might be debated at length on the basis of its subjectivity or the absence of objectivity of the said Minister. Everyone is subject to the same preventive law whether ordinary citizens or politicians. They cannot make use of their positions to interfere with the law just because he/she is a Member of Parliament or an important person in society.

Having deliberated on this subject it is indeed very rare these days to find a person who truly practices love and forgiveness, despite the reality that all religions, including Islam and Christianity, teach their followers to be compassionate. For example, the Qur'an we find that God states concerning forgiveness:

- "The repayment of a bad action is one equivalent to it. But if someone pardons and puts things right, his reward is with Allah..." (Q 42:40)

- "But if you pardon and exonerate and forgive, Allah is Ever-Forgiving, Most Merciful." (Q 64:14)

- "But if someone is steadfast and forgives, that is the most resolute course to follow." (Q 42:43)

Christianity likewise teaches its followers to be forgiving. For example, in Matthew 6:14-15, it states that, "For if you forgive men for their transgressions, your heavenly Father will also forgive you. But if you do not forgive men, then your Father will not forgive your transgressions." 
Love and forgiveness should be practised at all levels and should be cultivated and nurtured within us. The day we stop caring about this is the day that humanity dies. Love and forgiveness lie at the core of our spiritual needs. Look at how mankind has benefitted through love and forgiveness as contained in the Qur'an and the Sunna of the Prophet of Islam. One must oppose his own ego's desires and seek treatment for this disease with the healing force of acceptance of the divine decree and prayer on behalf of one's enemies in a way that suppresses the ego (nafs) (Hamza Yusuf, 2012:19). Interestingly Desmond Tutu had similar views on the same subject:

"Forgiving and being reconciled to our enemies or our loved ones are not about pretending that things are other than they are. It is not about patting one another on the back and turning a blind eye to the wrong. True reconciliation exposes the awfulness, the abuse, the hurt, the truth. It could even sometimes make things worse. It is a risky undertaking but in the end it is worthwhile, because in the end only an honest confrontation with reality can bring real healing. Superficial reconciliation can bring only superficial healing."

The acts of caring, helping, co-operating, assisting and tolerance are all traits of love and forgiveness. Despite its shortcomings Malaysia is a good example of a nation built on a spirit of harmony and tolerance. We may observe that despite its majority population being Muslims, other religions and cultures are allowed to coexist with the religion of the Federation. Malaysia is one country that has the most number of public holidays in the world compared to other countries, in order to accommodate differing religions and cultures. To celebrate these different festive seasons Malaysia originated the concept of "Open Houses". Even its popular local cuisine has been fused together from diverse multi-ethnic and multi-cultural communities.

If we ingrained into a community the sense of loving our fellow humans, working together, cooperating and collaborating with each other, then we would have a wonderful community. There would be a collective sense of identification, love and forgiveness. In that type of community there will not be civil war or internal conflicts, because people within such a community will feel satisfied and safe together since they are one. Together they will build their society for peace and harmony, not destroy or tear apart their mutual bonds.

We should cultivate and nurture this perception until it becomes part of our core values. In the corporate world there are codes and guidelines on governance and management to protect the environment and promote a culture of good governance between and among the corporate players. Perhaps a relevant parallel Ministry might examine the possibility of forging a blue print for love and 
forgiveness in governance which could include, inter alia: values and practices which might not have been taught in schools, and things which people generally have grown accustomed to take for granted.

Subjects to be taught such as 'adab' and 'pendidikan moral' (ethics) are vital to inculcate the intrinsic values of love and forgiveness. When I was in a religious school, one of the early subjects taught was ' $a d a b$ ', namely - the rules of behaviour. There was a need for this type of religious, cultural, ethical and value imprinting without colouring it with prejudice and bias. We have to persuade more people to be committed to serve voluntarily, not for money or power, but because it is necessary and beneficial to the common interest of all. We must recognise there remains much suffering around us in the world, even though there is far more wealth and riches.

When I served as a Committee Member on the Economic Consultative Council years ago, I proposed that instead of developing beautiful golf courses which took up 300 or 400 acres of land, these lands should be used to build low cost houses because nearby there were squatters who lacked even basic housing. Being an idealist I suggested to the ECC that the government should get rid of these golf courses and instead make use of the land to build low cost homes for the poor. Ungku Aziz who was then Chairman of the Poverty Committee remarked that I was even more radical than himself.

In the context of an organisation it is important to consider the interpersonal relationships and community relationship, especially in terms of honesty and positive moral values with the sense of rightness - like the Japanese. If we were to observe the discipline and behaviour of the Japanese after the Tsunami of 2012, we would be able to see how calm and composed they stood in the queue without agitation or panic. They did not react negatively nor abandon their principles in the face of this calamity, but stood firm on high moral grounds. They did not rush or grab when food or other supplies were distributed. Nor did they show any impatience or anger. All waited patiently for their turn. If these values could be inculcated into a community, then we could have a more healthy and sustainable communal life. This would mean everybody could share and live together, notwithstanding their differences be they tribal, religious, cultural, ethnic or racial. We should seek to transpose this mode of behaviour to the arena of nation states in their inter-state relations, international politics and international relations, living as a community of nations - the feeling of togetherness, cooperativeness, reciprocal working, helping each other, caring and sharing. We would then have a more peaceful, just and secure world order.

We must practice good moral values, something lacking today. We have the tendency to put individual freedom as our top priority without a balancing emphasis on the positive values of moral traits. We are even willing to act and do 
things against our human nature, against the very essence of our created nature. If we can inculcate such understanding and acceptance that freedom is not absolute but requires mature responsibility, and that everything has a limit, then we will more easily achieve peace and security. We have to learn to appreciate that not all of us are the same, but that diversity is natural and inherent to creation. This will help create a better global order, even better than what the UN practices. There is no need for a formal body to achieve this objective. A formal body could become the catalyst for dominating people and propagating hegemony, without exercising responsibilities. It might advocate values but without responsibilities, and where would this lead us to?

Learning love and forgiveness must start from the family and home-our upbringing from an early age. This is the most significant environment for inculcating love and forgiveness. It is therefore fundamental for every parent to express not only kind words but also to demonstrate and translate the sentiment of love and forgiveness into action for their children in their upbringing.

From my own personal experience it was my upbringing which made me the person I am today. My father was a teacher (ustaz) who strongly believed in cultivating family and religious values. So the home rituals of eating, dining, and praying together as a family were very much valued and observed. Some might say this was old fashioned, but these old ways must not be made light of as now; not only do they allow children to acquire proper habits and manners, they also would allow the parents to share their understanding of love and forgiveness, and therefore mutual respect for others would be attained.

These experiences are what make me convinced that although idealistic, incorporating love and forgiveness into governance is also realistic. Our parents have inculcated these principles in us from the time we were children. Unfortunately, many persons no longer practice these values consistently, especially towards those whom they do not know. Therefore those who do so are called 'idealists' as if they live in an unrealistic world. Fortunately, advances in information and communication technology provide an avenue for these idealists to spread their ideals in the real world. What is needed is for idealists to organise, to form virtual communities to spread these ideals. It is my contention that there is a need for more organisations dedicated to peace, love and forgiveness. NGOs established on the basis of love and forgiveness are very few in numbers, as most NGOs pursue their own agendas, often merely a cloak to support or promote certain political ideologies and philosophies. Idealists should not shy away from the battle of ideas. With greater dissemination of the importance of ethical principles in both domestic and international political arrangements, we may realistically alter the political imperatives. Nothing can stop an idea whose time has come. 


\section{Notes}

* Syed Hamid Albar, obtained his tertiary Education in Australia and the United Kingdom. He served as Judiciary and Legal - Magistrate for 2 years, and as Partner with Albar, Zulkifly \& Yap Advocates and Solicitors from 1986 to 1990. From 1990 to 2009 he served as Cabinet Minister. Specifically, from 1990 to 1995 he was Minister in the Prime Minister's Department and Minister of Law. From 1995 to 1999 he served as Minister of Defense. From 1999 to 2008 he was Minister of Foreign Affairs. From 2008 to 2009 he served as Minister of Home Affairs. He has been serving as Chairman of Land Public Transport Commission of Malaysia (S.P.A.D) since 3 June 2010, and reports directly to the Prime Minister. He is also a Council Member of the Asian Peace \& Reconciliation Counsel (APRC), and Special Envoy of the Organisation of Islamic Cooperation (OIC) for Asia. (Email: syedhamid.albar@yahoo.com)

1. This reflection is inspired by my interview with Dr. Alwi Shihab of the Fetzer Institute on 10 October 2013. I am glad to acknowledge Syed Ali Haidar, Syed Sadiq Albar, Thuraya Albar, Dr. Produyt Dutt, R. Suresh Kumar and Mariza Maarof for their views, comments and assistance. 